\title{
Insights into the Christian Office in Late Antiquity ${ }^{1}$
}

\author{
Annette von Stockhausen
}

As the Christian office is a well-researched topic and as the literature especially on the development of offices in the church in the first centuries (during and after New Testament times) is abundant ${ }^{2}$ and I therefore can

1 This is the English version of my originally German presentation, to which some notes were added for the publication. For the texts I cite in the following, I fell back on existing, even older English translations.

2 Cf. a select list of introductory or noteworthy titles: Ernst Dassmann, Ämter und Dienste in den frühchristlichen Gemeinden, Hereditas 8 (Bonn: Borengässer, 1994); Wolf-Dieter Hauschild, "Amt V. Kirchengeschichtlich 1. Alte Kirche," in $R G G^{4}$ I (1998), 426-427; Wolf-Dieter Hauschild, "Bischof II. Kirchengeschichtlich," in $R G G^{4}$ I (1998), 1615-1618; Wolf-Dieter Hauschild, "Presbyter/ Presbyterium II. Kirchengeschichtlich," in $R G G^{4}$ VI (2003), 1612-1614; Thomas Kramm, "Amt," in RAC Suppl. 1 (2001), 350-401; Richard P. C. Hanson, "Amt/ Ämter/Amtsverständnis. V. Alte Kirche," in TRE 2 (1978), 533-552; Paul F. Bradshaw, "Priester/Priestertum. III. Christliches Priesteramt. 1. Geschichtlich," in TRE 27 (1997), 414-421. On the legal view on the Christian office, cf. Karl Leo Noethlichs, "Zur Einflussnahme des Staates auf die Entwicklung eines christlichen Klerikerstandes," in JbAC 15 (1972), 136-153; Karl Leo Noethlichs, "Materialien zum Bischofsbild aus den spätantiken Rechtsquellen," in JbAC 16 (1973), 28-59. On the role in society, cf. Henry Chadwick, The Role of the Christian Bishop in Ancient Society: Protocol of the Thirty-Fifth Colloquy, 25 February 1979 (Berkeley, CA: The Center, 1980). In more recent times, there has also been a lot of research done on the developments in Late Antiquity; cf. Éric Rebillard und Claire Sotinel, eds., L'évêque dans la cité du IVe au Ve siècle. Image et autorité. Actes de la Table ronde organisée par l'Istituto Patristico Augustinianum et l'École française de Rome, Rome, 1er et 2 décembre 1995, Collection de l'École Française de Rome 248 (Rome: École française de Rome, 1998); Pauline Allen und Wendy Mayer, "Through a Bishop's Eyes: Towards a Definition of Pastoral Care in Late Antiquity," in Augustinianum 40 (2000): 345-397; Lellia Cracco Ruggini, "Prêtre et fonctionnaire. L'essor d'un modèle épiscopal aux IVe-Ve siècles," in Antiquité Tardive 7 (2000): 175-186; Wendy Mayer, "Patronage, Pastoral Care and the Role of the Bishop at Antioch," in Vigiliae Christianae 55/1 (2001): 58-70; Georg Schmelz, Kirchliche Amtsträger im spätantiken Ägypten nach den Aussagen der griechischen und koptischen Papyri und Ostraka, Archiv für Papyrusforschung und verwandte Gebiete. Beiheft 13 (München et al.: Saur, 2002); Sabine Hübner, Der Klerus in der Gesellschaft des spätantiken Kleinasiens, Altertumswissenschaftliches Kolloquium 15 (Stutt- 
in this short paper only point to some aspects connected with the Christian office, I'd like to highlight the profile and the roles which the bearers of the Christian office have assumed. Due to the enormous amount of sources, I will especially focus on the Roman Empire, on "orthodox" Christianity and on the period from the $4^{\text {th }}$ to the $6^{\text {th }}$ century, when all Christian offices which have influenced the life and developments of the Christian church in its different denominations during the Middle Ages and until our times are established.

In order to get as wide a picture as possible, I will examine different genres of Christian sources: (1) legal texts, (2) a hagiographic text, and (3) a deliberative text.

\section{The office in Christian legal texts}

Christian legal texts like the so-called church orders ${ }^{3}$ are an important source for learning about the respective profiles of and the different roles connected to the offices, as well as the expectations people have of the offices.

The "Apostolic Constitutions", which were compiled at the end of the $4^{\text {th }}$ century and which recur in older collections of Christian law, are an exemplary exponent of such Christian legal texts. In book VIII we find all regulations on the offices in the church. ${ }^{4}$ They refer to the offices of bishop (VIII 5 sqq.), presbyter (16), deacon (17 sq.), deaconess (19 sq.), sub-deacon (21), lector (22), confessor (23), virgin (24), widow (25), and exorcist (26).

gart: Steiner, 2005); Claudia Rapp, Holy Bishops in Late Antiquity: The Nature of Christian Leadership in an Age of Transition (Berkeley, CA: University of California Press, 2005); Ewa Wipszycka, "The Institutional Church," in Roger S. Bagnall, ed., Egypt in the Byzantine World, 300-700 (New York et al.: Cambridge Univ. Press, 2008), 331-349.

3 A good and recent overview on the ancient church orders can be found in Johannes Mühlsteiger, Kirchenordnungen. Anfänge kirchlicher Rechtsbildung, Kanonistische Studien und Texte 50 (Berlin: Duncker \& Humblot, 2006).

4 The Apostolic Constitutions make use of the early $3^{\text {rd }}$-century "Apostolic Tradition". 
In these passages on the different offices, the most revealing parts for our question are the prayers spoken at the ordination $\left(\chi \varepsilon 1 \rho \circ \tau\right.$ oví $\left.\alpha^{5}\right)$, because there we hear about the ideal of the office.

The prayer for the ordination of a bishop states the following: ${ }^{6}$ The

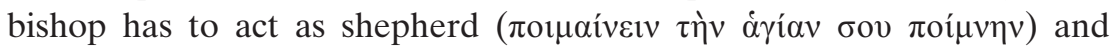

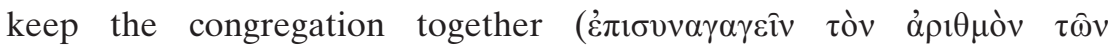
$\sigma \omega \zeta o \mu \varepsilon \dot{\varepsilon}(\omega v)$, he has to offer service to God day and night as high priest

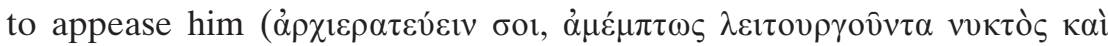

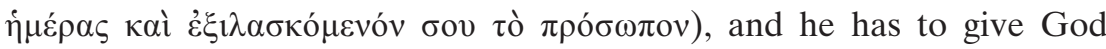

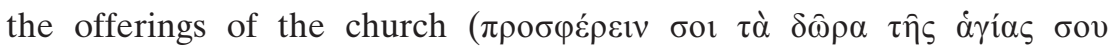

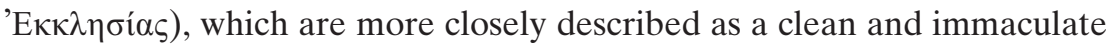

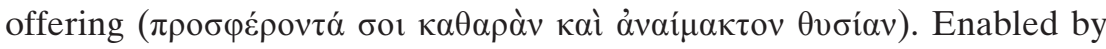
the Holy Spirit and through Jesus Christ, the bishop can remit sins

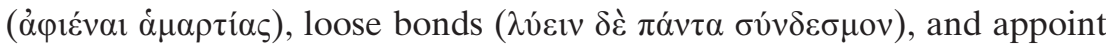

5 The differentiation between the offices I talked about earlier is also manifest in

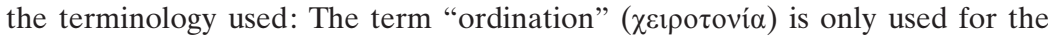
bishop, the presbyter, the deacon, and the subdeacon; in the case of deaconess

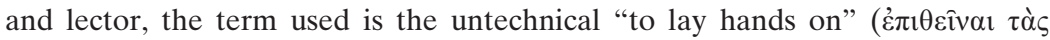
$\chi \varepsilon i \hat{p} \alpha \varsigma)$. The offices of confessor, virgin, widow, and exorcist are distinct from that insofar as it is noted that due to the special character of these offices no ordination is needed (confessor, widow, exorcist) or known from the New Testament (virgin).

6 I cite here only the most relevant part of it (Const.Ap. VIII 5,6 sq., Bruce Manning Metzger, ed., "Les constitutions apostoliques III. Livres VII et VIII", Sour-

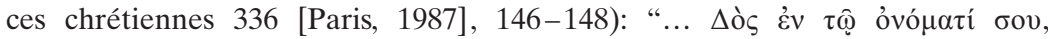

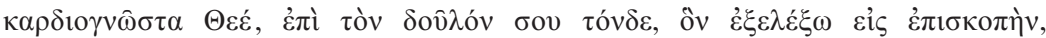

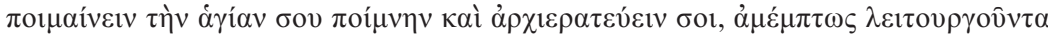

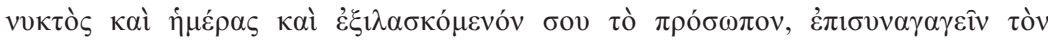

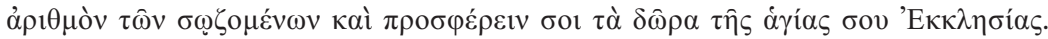

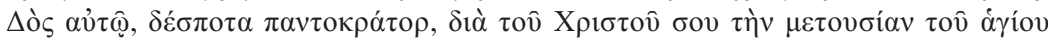

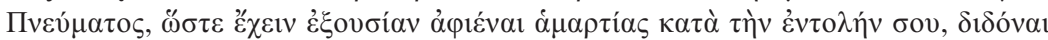

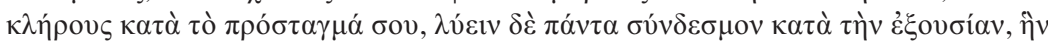

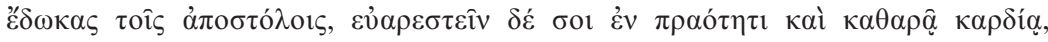

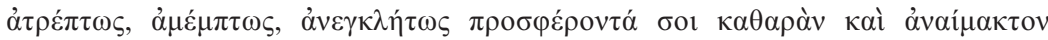

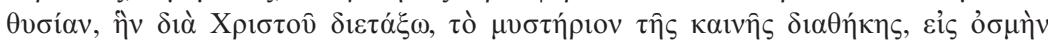

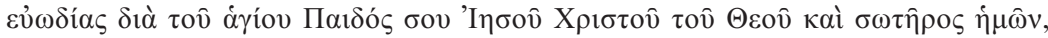

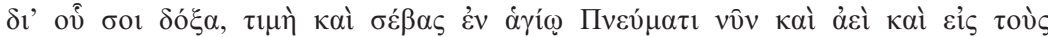

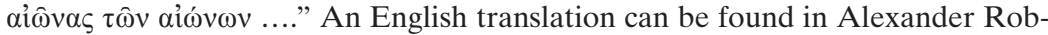
erts and James Donaldson, The Ante-Nicene Fathers, vol. 7, Lactantius, Venantius, Asterius, Victorinus, Dionysius, Apostolic Teaching and Constitutions, Homily and Liturgies, American repr. of the Edinburgh ed. (Edinburgh et al.: Clark et al., 1989), 482 sq. Of course there are obvious references to Old and New Testament conceptions and terminology. 


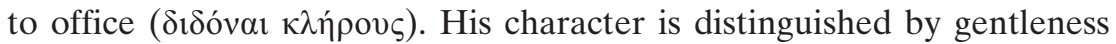
and a pure heart ( $\dot{\varepsilon} v \pi \rho \alpha o ́ \tau \eta \tau \imath ~ \kappa \alpha i ̀ ~ \kappa \alpha \theta \alpha \rho \hat{\alpha} \kappa \alpha \rho \delta i ́ \alpha)$, by constancy

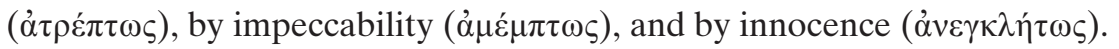

Quite similar, but with distinct restrictions, the Apostolic Constitutions describe the office of the priest: ${ }^{7}$ The priest is selected by the

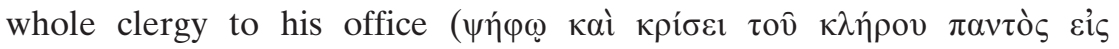
$\pi \rho \varepsilon \sigma \beta v \tau \dot{\varepsilon} \rho 10 v \dot{\varepsilon} \pi \mathrm{\imath} \delta 0 \theta \dot{\varepsilon} v \tau \alpha$ ), but can fulfil his duty also only by the gift of

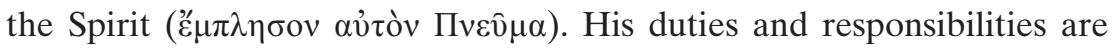
to assist the bishop in his task to govern the congregation ( $\sigma v \mu \beta 0 v \lambda i \alpha \varsigma$

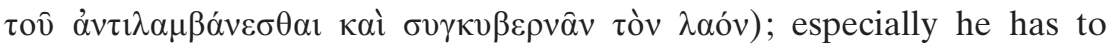

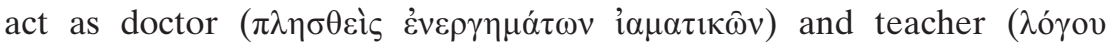

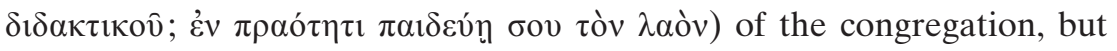

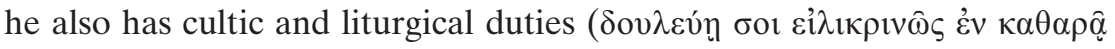

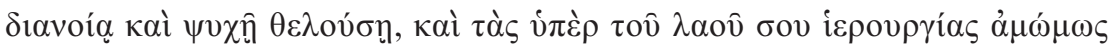
$\dot{\varepsilon} \kappa \tau \varepsilon \lambda \hat{)})$.

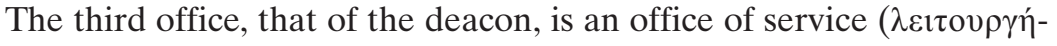

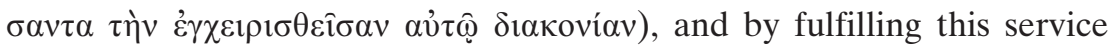

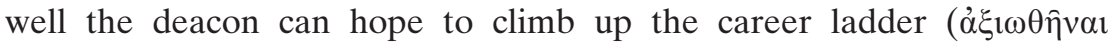
$\beta \alpha \theta \mu \mathrm{ov})$ and become a priest or bishop. ${ }^{8}$

At the end of book VIII of the Apostolic Constitutions we find a col-

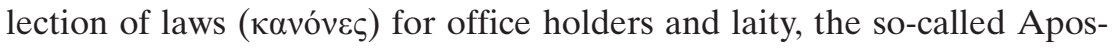

7 Const.Ap. VIII 16,4 sq., Metzger, ed., "Les constitutions apostoliques III. Livres

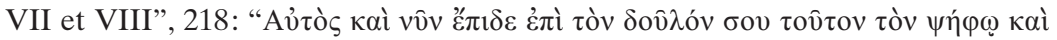

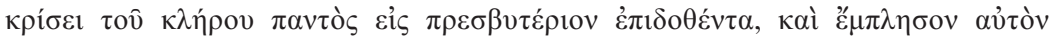

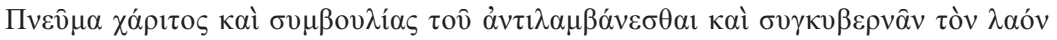

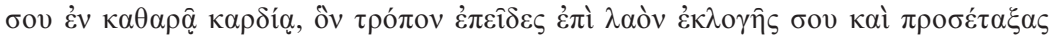

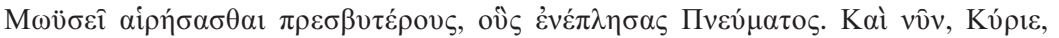

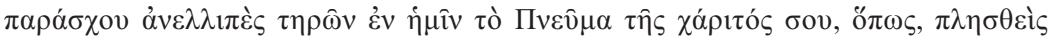

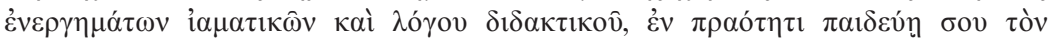

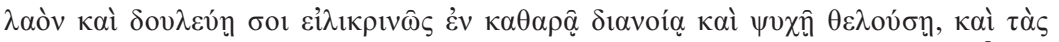

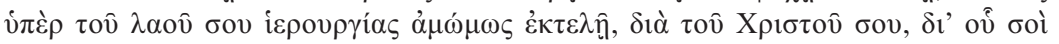

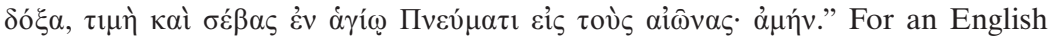
translation, see Roberts and Donaldson, The Ante-Nicene Fathers, vol. 7, 492.

8 Const.Ap. VIII 18,2 sq., Metzger, ed., "Les constitutions apostoliques III. Livres

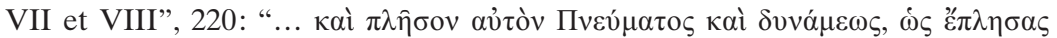

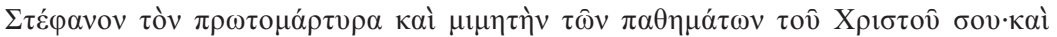

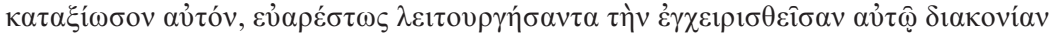

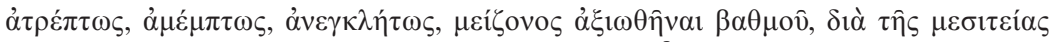

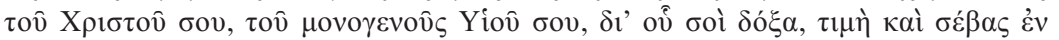

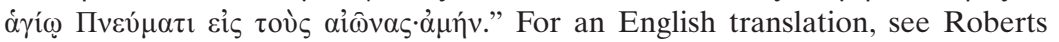
and Donaldson, The Ante-Nicene Fathers, vol. 7, 492. Cf. the prayer for the deaconess in VIII 20,2. 
tolic Canons. ${ }^{9}$ They provide us with a more "realistic" view on the offices holders and the way the offices were executed by them, as they regulate disputed or possibly problematic issues.

Thus we learn about the formal procedures connected with the Christian office like ordination ${ }^{10}$, the jurisdiction of the bishops ${ }^{11}$, and the primacy of the bishop ${ }^{12}$, which implies also his power in financial matters, ${ }^{13}$

9 This collection is a compilation of traditional regulations (among others the canons of some $4^{\text {th }}$-century synods), most probably made at the end of the $4^{\text {th }}$ century in Syria.

10 Can. 1 (Metzger, ed., "Les constitutions apostoliques III. Livres VII et VIII",

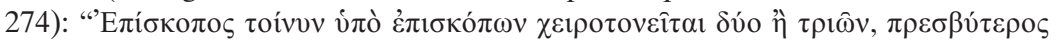

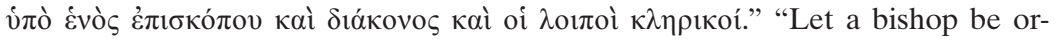
dained by two or three bishops. A presbyter by one bishop, as also a deacon, and the rest of the clergy." (Translation by Roberts and Donaldson, The Ante-Nicene Fathers, vol. 7, 500).

11 Can. 14 (Metzger, ed., "Les constitutions apostoliques III. Livres VII et VIII",

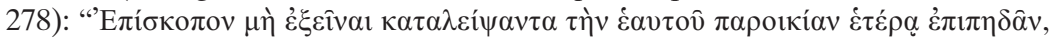

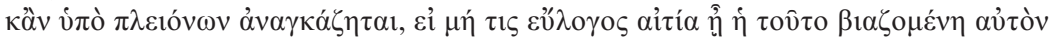

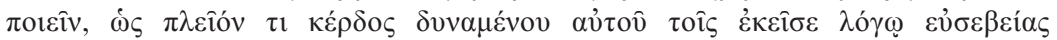

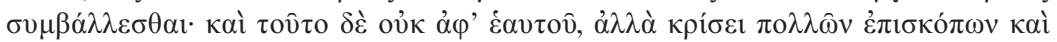

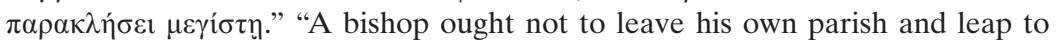
another, although the multitude should compel him, unless there be some good reason forcing him to do this, as that he can contribute much greater profit to the people of the new parish by the word of piety; but this is not to be settled by himself, but by the judgment of many bishops, and very great supplication. (Translation by Roberts and Donaldson, The Ante-Nicene Fathers, vol. 7, 501.)

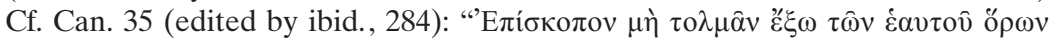

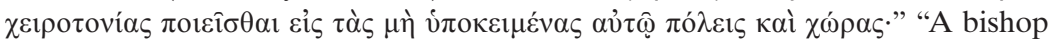
must not venture to ordain out of his own bounds for cities or countries that are not subject to him." (Translation by Roberts and Donaldson, The Ante-Nicene Fathers, vol. 7, 502.)

12 Can. 39 (Metzger, ed., "Les constitutions apostoliques III. Livres VII et VIII",

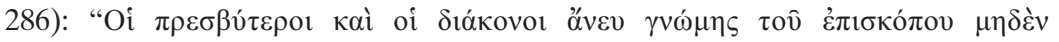

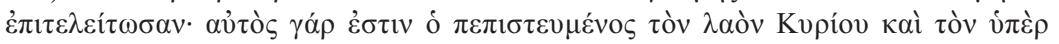

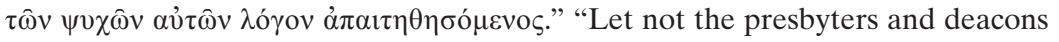
do anything without the consent of the bishop, for it is he who is entrusted with the people of the Lord, and will be required to give an account of their souls." (Translation by Roberts and Donaldson, The Ante-Nicene Fathers, vol. 7, 502.)

13 Can. 41 (Metzger, ed., "Les constitutions apostoliques III. Livres VII et VIII",

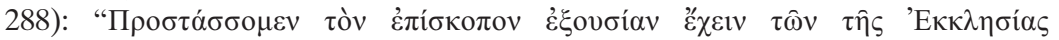

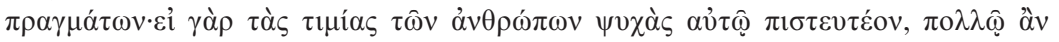

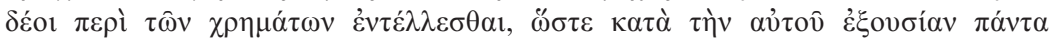

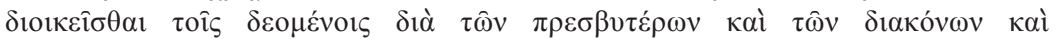

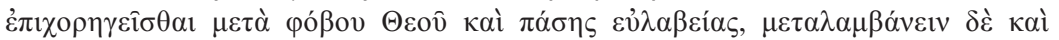

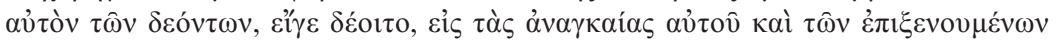


or with the convening of bishops to synods, in order to decide about the matters of the church. ${ }^{14}$ Through laws like Can. $6^{15}$ or Can. $20^{16}$, which prohibit involvement in matters of the world, we also learn about the general distinction drawn between the clergy and the laity and the notion of an otherworldliness of the clergy.

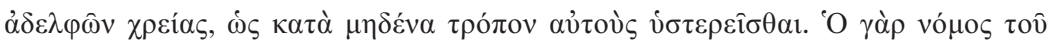

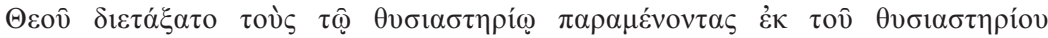

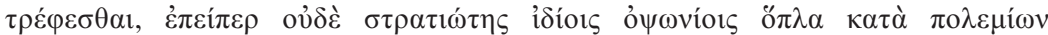

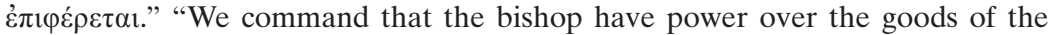
Church; for if he be entrusted with the precious souls of men, much more ought he to give directions about goods, that they all be distributed to those in want, according to his authority, by the presbyters and deacons, and be used for their support with the fear of God, and with all reverence. He is also to partake of those things he wants, if he does want them, for his necessary occasions, and those of the brethren who live with him, that they may not by any means be in straits: for the law of God appointed that those who waited at the altar should be maintained by the altar; since not so much as a soldier does at any time bear arms against the enemies at his own charges." (Translation by Roberts and Donaldson, The Ante-Nicene Fathers, vol. 7, 502.)

14 Can. 37 (Metzger, ed., "Les constitutions apostoliques III. Livres VII et VIII",

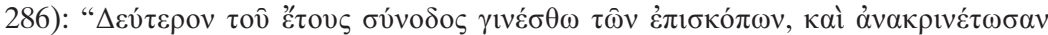

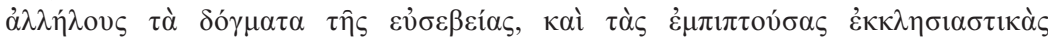

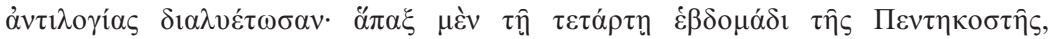

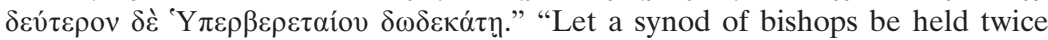
in the year, and let them ask one another the doctrines of piety; and let them determine the ecclesiastical disputes that happen-once in the fourth week of Pentecost, and again on the twelfth of the month Hyperberetæus." (Translation by Roberts and Donaldson, The Ante-Nicene Fathers, vol. 7, 502.)

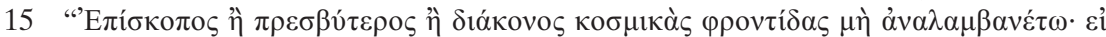
$\delta \grave{\varepsilon} \mu \eta \dot{n}, \kappa \alpha \theta \alpha \iota \rho \varepsilon i ́ \sigma \theta \omega . "$ (Metzger, ed., "Les constitutions apostoliques III. Livres VII et VIII", 276.) "Let not a bishop, a priest, or deacon undertake the cares of this world; but if he do, let him be deprived." (Translation by Roberts and Donaldson, The Ante-Nicene Fathers, vol. 7, 500.)

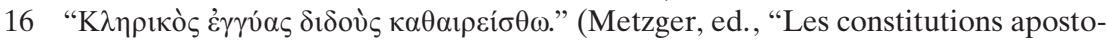
liques III. Livres VII et VIII", 280.) "Let a clergyman who becomes a surety be deprived." (Translation by Roberts and Donaldson, The Ante-Nicene Fathers, vol. 7, 501.) 


\section{The ideal bishop - a hagiographic approach}

With the life of Bishop Maximianus of Ravenna" in the "Book of Pontiffs", a collection of lives of the bishops of Ravenna written by Agnellus of Ravenna in the $9^{\text {th }}$ century, we enter the genre of hagiography and get further insight into the ideal and the reality of the Christian office. At the same time, Agnellus' description of the office of bishop confirms the observations we made on the Apostolic Constitutions and Canons.

Agnellus praises Maximianus and the way he was acting towards the end of his vita with the following words: ${ }^{18}$

17 Maximianus, who was born in Pola in Istria, was between 546 and 556 archbishop of Ravenna, since 493 the capital of the Ostrogotic kingdom and since 540 again in possession of the Roman (Byzantine) Empire. Amongst other things, he completed the famous Ravennese church San Vitale in 547, where we also find a portrait of him at the side of Emperor Justinianus in a mosaic panel at the foot of one of the apse side walls; cf. Agnellus, lib. pont. 77 and Deborah Mauskopf Deliyannis, Ravenna in Late Antiquity (New York: Cambridge Univ. Press, 2010), $223-249$.

Generally it would be very instructive to include in this short study the selfrepresentation of bishops in mosaics (and other forms of Christian art) like the mosaics in Santa Maria Maggiore in Rome commissioned by Sixtus III (see the Roman Liber pontificalis, ch. 46).

18 Agnellus of Ravenna, lib. pont. 82; the translation is by Deborah Mauskopf Deliyannis, The Book of Pontiffs of the Church of Ravenna (Washington, DC: Catholic Univ. of America Press, 2004), 195 sq. The Latin text can be found in the edition by Oswald Holder-Egger, "Agnelli qui et Andreas Liber pontificalis ecclesiae Ravennatis", in Scriptores rerum Langobardicarum et Italicarum saec. VIIX, MGH SS rer. Lang. 1 (Hannover, 1878), 332. "Pauca de multis diximus, plura de eo invenietis, quam hic legistis. Nunquam suas laniavit oves, nunquam mordit, nunquam percussit, sed refovit eloquiis, nutrivit alimentis, monuit vagos, revocavit errantes, collegit dispersos, ministravit inopi, condoluit tribulanti. Miror, modo iste, qui ex alterius fuit sede, sic se cum suis disposuit ovibus, quod nullum contra eum sermonem unquam multavit: modo ex nobis ipsis pastorem habentes, postquam sedes adipiscunt, dentibus devorare volunt nec ullam nesciunt habere misericordiam; plus sublimitatem seculi quam caeleste gloria quaerunt; non participant cum ovibus, sed res ecclesiae soli deglutiunt, et tales ex ipsis opibus nutriti fiunt, qui nec ecclesia serviunt, sed magis depopulant, neque pro dimissoris animam preces Deo ei fundunt. Tunc ipsae oves cotidie moerendo clamant ad Dominum, dicentes: 'Erue nos, Domine, de captione dentium pastoris nostri, quia non mercenarii locum, sed crudelitatem lupi tenet, omnes nos in sua extollentia cunsumit'. Hic vero beatissimus Maximianus nunquam talia peregit, sed cum mansuetudine inimicorum suorum corda humiliavit, ut adimpleret, quod scriptum est: 'Noli vinci a malo, sed vince in bono malum', et alibi: 'In patientia vestra possidebitis animas vestras." 
We have said a few things out of many; you will find more about him than you have read here. He never ravaged his sheep, never hurt them, never struck them, but refreshed them with words, fed them with food, warned the wandering, recalled the errant, collected the dispersed, ministered to the needy, condoled the one in trouble.

I marvel at how this one, who was from another see, thus behaved with his sheep, that no one ever raised up any word against him. Now that we have pastors from among ourselves, after they obtain the see, they want to devour us with their teeth, nor do they know how to have any mercy. They seek secular heights rather than heavenly glory; they do not participate with their sheep, but they devour the possessions of the church alone; and fed from this wealth become such as do not serve the church, but rather depopulate it, nor do they pour out prayers to God for the soul of him who disposed of these possessions. Then these sheep daily cry in mourning to the Lord, saying, "Free us, Lord, from the captivity of the teeth of our shepherd, since he has not the place of a mercenary, but the cruelty of a wolf; he consumes us all in aggrandizing his own possessions."

This most blessed Maximian never did such things, but with kindness he humiliated the hearts of his enemies, that he might fulfill what is written, "Be not overcome by evil, but overcome evil by good," and again, "In your patience you shall possess your souls."

Unsurprisingly Agnellus, too, resorts here first and foremost to the metaphor of the good shepherd when he speaks about Bishop Maximianus, but by doing so he also designates the activities a bishop has to execute in order to serve his congregation well. These activities comprise teaching, correction, and edification (refovit eloquiis; monuit vagos; revocavit errantes; collegit dispersos) on the one hand and care of the needy (nutrivit alimentis; ministravit inopi; condoluit tribulanti) on the other hand.

After that Agnellus introduces the embodiment of the evil bishop by way of antithesis to Maximianus, and we can conjecture that he draws here at least partly from real-world examples. He envisions bishops who are not shepherds but wolves, who have no mercy (nec ullam nesciunt habere misericordiam), and who care not for the needy (non participant cum ovibus). Those bishops are only looking for their earthly glory ( $s u b$ limitatem seculi quaerunt) and revenue (res ecclesiae soli deglutiunt), and by behaving like that they attract candidates to the office who are even worse than themselves (tales ex ipsis opibus nutriti fiunt, qui nec ecclesia serviunt, sed magis depopulant, neque pro dimissoris animam preces Deo ei fundunt). 


\section{John Chrysostom as exemplary bishop}

John Chrysostom was another exemplary bishop. He passed all ranks on the career ladder up to the bishopric: $:^{19}$ In 368 he was baptised, and in 371 he became lector in Antioch; after having lived for six years as an ascetic in the vicinity of Antioch, he returned to the city and was selected as deacon by Bishop Meletios on the eve of the Council of Constantinople (381). In 386 Bishop Flavian ordained him to the priesthood and Chrysostom became the famous preacher we know him for. In 398 he was chosen as bishop of Constantinople ${ }^{20}$, where he ruled until 404, when he was exiled due to his administration of the office and the reforms of the Constantinopolitan church he had initiated, ${ }^{21}$ as well as due to his general behaviour as bishop and towards the imperial court. On September 14, 407, he died in exile.

Most probably during the period he was deacon in Antioch and influenced by Gregory of Nazianzus' oration no. 2 (De fuga sua), John Chrysostom wrote a treatise in dialogue form, "On Priesthood" (De sacerdotio), in order to reform existing grievances. ${ }^{22}$ In it he formulates a theory of the Christian office, which is totally affected by a concept of

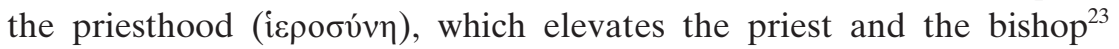

19 On the career of John Chrysostom, cf. for example Wendy Mayer and Pauline Allen, John Chrysostom, The Early Church Fathers (New York: Routledge, 2000). It is deeply interwoven with $4^{\text {th }}$-century church politics and dogmatic controversies.

20 Cf. especially Wendy Mayer, "John Chrysostom as Bishop: The View from Antioch," in The Journal of Ecclesiastical History 55/3 (2004): 455-466.

21 Cf. for example the article by Nathanael Andrade, "The Processions of John Chrysostom and the Contested Spaces of Constantinople," in Journal of Early Christian Studies 18/2 (2010): 161-189.

22 Cf. especially Hermann Dörries, "Die Erneuerung des kirchlichen Amtes im vierten Jahrhundert. Die Schrift De sacerdotio des Johannes Chrysostomus und ihre Vorlage, die Oratio de fuga sua des Gregor von Nazianz," in Bernd Moeller and Gerhard Ruhbach, eds., Bleibendes im Wandel der Kirchengeschichte. Kirchenhistorische Studien. FS Hans von Campenhausen (Tübingen: Mohr, 1973), 1-46; Jutta Tloka, Griechische Christen - christliche Griechen. Plausibilisierungsstrategien des antiken Christentums bei Origenes und Johannes Chrysostomos, Studien und Texte zu Antike und Christentum 30 (Tübingen: Mohr Siebeck, 2005), 226-244; Gus George Christo, Bishops as Successors to the Apostles according to John Chrysostom: Ecclesiastical Authority in the Early Church (Lewiston, NY et al.: Edwin Mellen Press, 2008).

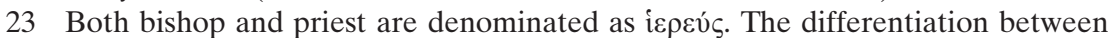
the two offices in the treatise is not always clear, as sometimes (like in sac. I 3) 
(clergy) above the congregation (laity). I will now highlight some points John Chrysostom claims in his lengthy treatise.

According to Chrysostom, the exalted position of the priest is justified because the priest is intermediator between heaven and earth and therefore also responsible for the salvation of his flock. He states: ${ }^{24}$

$[\mathrm{H}] \mathrm{e}$ will then clearly see what great honor $[\tau 1 \mu \eta \dot{]}$ the grace of the Spirit has vouchsafed to priests; since by their agency these rites are celebrated, and others nowise inferior to these both in respect of our dignity and our salvation. For they who inhabit the earth and make their abode there are entrusted with the administration of things which are in Heaven, and have received an authority [ $\hat{\varepsilon} \xi o v \sigma i ́ \alpha]$ which God has not given to angels or archangels. For it has not been said to them, "Whatsoever ye shall bind on earth shall be bound in Heaven, and whatsoever ye shall loose on earth shall be loosed in Heaven." They who rule on earth have indeed authority to bind, but only the body: whereas this binding lays hold of the soul and penetrates the heavens; and what priests do here below God ratifies above, and the

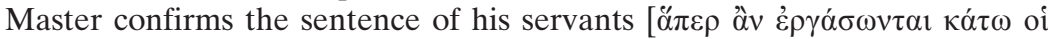

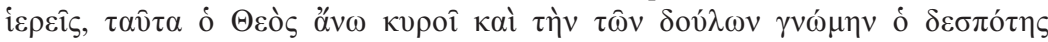
$\beta \varepsilon \beta \alpha 10 \hat{]}]$....

Besides acting as intermediator, the priest is representing Christ on earth as well, as he is the gateway to salvation: $:^{25}$

These (sc. the priests) verily are they who are entrusted with the pangs of spiritual travail and the birth which comes through baptism: by their

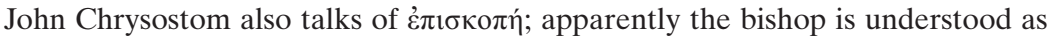
the priestly office proper (see above).

24 Sac. III 5. Translation by Philip Schaff, A Select Library of the Nicene and PostNicene Fathers of the Christian Church, vol. 9, Saint Chrysostom: On the priesthood; Ascetic treatises; Select homilies and letters; Homilies on the statues (Edinburgh et al.: Clark et al., 1889), 47; edition of the Greek text by AnneMarie Malingrey, Jean Chrysostome. Sur le sacerdoce. Dialogue et homélie, Sources chrétiennes 272 (Paris: Éd. du Cerf, 1980).

25 Sac. III 6. Translation by Schaff, A Select Library, vol. 9, 47. Cf. sac. VI 4 (translation ibid., 76), "For he who acts as an ambassador on behalf of the whole citybut why do I say the city? on behalf of the whole world indeed-prays that God would be merciful to the sins of all, not only of the living, but also of the departed. What manner of man ought he to be? For my part I think that the boldness of speech of Moses and Elias, is insufficient for such supplication. For as though he were entrusted with the whole world and were himself the father of all men, he draws near to God, beseeching that wars may be extinguished everywhere, that tumults may be quelled; asking for peace and plenty, and a swift deliverance from all the ills that beset each one, publicly and privately; and he ought as much to excel in every respect all those on whose behalf he prays, as rulers should excel their subjects." 
means we put on Christ, and are buried with the Son of God, and become

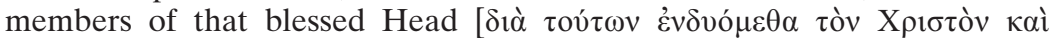

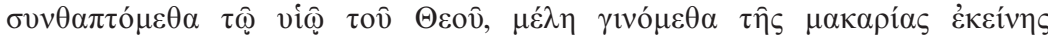
$\kappa \varepsilon \varphi \alpha \lambda \eta \bar{\eta} \varsigma$. Wherefore they might not only be more justly feared by us than rulers and kings, but also be more honored than parents; since these begat us of blood and the will of the flesh, but the others are the authors of our birth from God, even that blessed regeneration which is the true freedom and the sonship according to grace.

Because the priest has such an elevated status, he is also subject to special requirements regarding his character and morals. Absolute purity is required of him, as he is the one in the community who is dealing with heavenly powers: ${ }^{26}$

And whenever he invokes the Holy Spirit, and offers the most dread sacrifice, and constantly handles the common Lord of all, tell me what rank shall we give him? What great purity and what real piety must we demand of him? For consider what manner of hands they ought to be which minister in these things, and of what kind his tongue which utters such words, and ought not the soul which receives so great a spirit to be purer and holier than anything in the world? At such a time angels stand by the Priest; and the whole sanctuary, and the space round about the altar, is filled with the powers of heaven, in honor of Him who lieth thereon. For this, indeed, is capable of being proved from the very rites which are being then celebrated.

But the priest also needs more "earthly" skills. He has to be a good orator, ${ }^{27}$ as preaching is one of his most important duties and responsibilities, ${ }^{28}$ and he has generally to be an educated man $:^{29}$

26 Sac. VI 4 (translation by Schaff, A Select Library, vol. 9, 76). Cf. Sac. III 14 (translation ibid., 52), "And apart from these things, the faults of insignificant men, even if they are exposed, inflict no injury worth speaking of upon any one: but they who occupy the highest seat of honor are in the first place plainly visible to all, and if they err in the smallest matters these trifles seem great to others: for all men measure the sin, not by the magnitude of the offence, but by the rank of the offender. Thus the priest ought to be protected on all sides by a kind of adamantine armour, by intense earnestness, and perpetual watchfulness concerning his manner of life, lest some one discovering an exposed and neglected spot should inflict a deadly wound: for all who surround him are ready to smite and overthrow him: not enemies only and adversaries, but many even of those who profess friendship."

27 Cf. Sac. IV 5 (translated by Schaff, A Select Library, vol. 9, 66), "In short, to meet all these difficulties, there is no help given but that of speech, and if any be destitute of this power, the souls of those who are put under his charge (I mean of the weaker and more meddlesome kind) are no better off than ships continually 
Priests are the salt of the earth. ... For the Priest ought not only to be thus pure as one who has been dignified with so high a ministry, but very discreet, and skilled in many matters, and to be as well versed in the affairs of this life as they who are engaged in the world, and yet to be free from them all more than the recluses who occupy the mountains. For since he must mix with men who have wives, and who bring up children, who possess servants, and are surrounded with wealth, and fill public positions, and are persons of influence, he too should be a many-sided man-I say many-sided, not unreal, nor yet fawning and hypocritical, but full of much freedom and assurance, and knowing how to adapt himself profitably, where the circumstances of the case require it, and to be both kind and severe, for it is not possible to treat all those under one's charge on one plan, since neither is it well for physicians to apply one course of treatment to all their sick, nor for a pilot to know but one way of contending with the winds. For, indeed, continual storms beset this ship of ours, and these storms do not assail from without only, but take their rise from within, and there is need of much condescension, and circumspection, and all these different matters have one end in view, the glory of God, and the edifying of the Church.

\section{Summary}

The Apostolic Constitutions and the Apostolic Canons, Maximianus of Ravenna and John Chrysostom served here for exemplary approaches to the Christian office in Late Antiquity.

As we can see from these examples and from further available sources, the Christian office presents itself by the beginning of the $4^{\text {th }}$ century in the following way: In the period examined here, there are many different offices in the church, which are built up in a pyramidal layout. On top and reckoned as the office proper is the bishop, who is the leader of the local Christian community, ${ }^{30}$ followed by the offices of priest and of dea-

storm-tossed. So that the Priest should do all that in him lies, to gain this means of strength."

28 Cf. Sac. V 1 and 7.

29 Sac. VI 4; translation by Schaff, A Select Library, vol. 9, 76 sq.

30 On the "monarchic" bishop, cf. Ernst Dassmann, "Zur Entstehung des Monepiskopats," in JbAC 17 (1974), 74-90; Georg Schöllgen, "Monepiskopat und monarchischer Episkopat. Eine Bemerkung zur Terminologie," ZNW 77 (1986): $146-151$. In the $4^{\text {th }}$ century (and onwards) there is also a hierarchical differentiation in the office of bishop: The head of the church in a metropolis, the provincial capital, is called "metropolitan" and has authority over the other bishops in the province. Besides these are the "chorbishops" (an office later disap- 
$\operatorname{con}^{31}$ with more specialised offices like lector, cantor, gate keeper, and grave digger below. Besides these there are some special offices for women, like deaconess, widow, and virgin, which are also subordinate to the bishop (and the priests). Most, but not all of these offices have a strong connection to worship, ${ }^{32}$ but at the same time mission, teaching, intercession, direction of the community, caring for the welfare of the community, and last but not least, administration are also highly important functions of the bishops (and by delegation also of the priests and deacons). ${ }^{33}$

In connection with the congregation there is a clear distinction between the bishop (as well as the other members of the clergy) as "priest" and "holy man" and the "laity", which expresses itself also in clothes and phenomena like the tonsure or celibacy as well as in the episcopal selfrepresentation. These are aspects which would deserve closer inspection. $^{34}$

pearing) in rural areas, who are subject to the bishop in the city and who have limited rights.

31 Comparable to the differentiation of the office of bishop there is also an increasing differentiation of the offices of priest and deacon.

32 I'm generalizing here, as the connection of some offices to the Christian worship (and sometimes also their bare existence, especially in case of the offices for women) is dependent on time and place, cf. the titles mentioned in fn. 1 .

33 Cf. Mayer, "Patronage, Pastoral Care and the Role of the Bishop at Antioch", 60; Rapp, Holy Bishops in Late Antiquity, 23.

34 Cf. fn. 17. 
